\title{
Phenomenon of Umrah Backpacker Implementation: Case Studies in Bekasi and Bogor
}

\author{
Fakhruddin $\mathrm{M}^{1}$, Achmad Ubaidillah ${ }^{2}$ \\ \{Oedein@gmail.com ${ }^{1}$, Jaya.rimbang@gmail.com ${ }^{2}$ \}
}

\begin{abstract}
Center for Research and Development Ministry of Religious Affairs of The Republic of Indonesia, J1. M.H. Thamrin No. Jakarta Pusat1, Center for Pesantren Studies',Jl. Pagentongan, No. 28 Pesantren Al-Falak Kota Bogor ${ }^{2}$
\end{abstract}

\begin{abstract}
The Umrah backpacker becomes an interesting phenomenon in Indonesia along with the limited hajj quota and the increasing enthusiasm to carry out Umrah. At first, Umrah backpacker was seen by some as illegal. The view arises because its practice is considered not to follow the procedures set by the Indonesian government through the Directorate of Hajj and Umrah, the Ministry of Religious Affairs. However, this study found that the Umrah backpacker pilgrim does not perform the worship independently. They still officially register through travel parties that already have permission to hold Umrah services. The polemic of Umrah backpacker practices and regulations cannot be separated from the definition of "Umrah Backpacker" which has not been agreed upon by the parties concerned and causes confusion. Therefore, the term's definition is very important to look for.
\end{abstract}

Keywords: Umrah Backpacker, Regulations, Term Definition Problem

\section{Introduction}

Indonesia is a country with the largest Muslim majority in the world with a percentage of 87.2 or 209.12 million of its total population in 2010 , which is reaching 237.6 million people (BPS, 2010). The Muslim population is predicted to increase to 229.62 million by 2020 (Kusnandar, 2019). Most of the Muslim population in Indonesia is devout in worship. Research by Pew Research Center (Poushter \& Fetterolf, 2019) shows that 83 percent of Indonesians who believe in religion have a big influence on their country compared to 20 years ago, followed by the Philippines (54\%) and India (54\%).

Regarding to its research, one of manifestation of moslem obedience to GOD is the umrah worhsip which did by the Indonesian moslem. In Islamic doctrine, one of the obligatory acts of worship is to carry out the hajj which is intended for capable Muslims. Hajj is a visit to the holy land, Mecca, to carry out a series of acts of worship in accordance with the conditions, pillars, and time specified.

Apart from the obligatory Hajj, it turns out that Umrah, which is carried out in the same holy place, is also very enticing to the public. The Umrah congregation from Indonesia is the largest in Saudi Arabia. This is because the hajj quota is limited and its waiting period is very long. Umrah is worship that is the same as hajj, but its law is sunnah and the time is not determined. According to records, in 2018 the number of Indonesian Umrah pilgrims reached $1,050,000$ people (Sutarno, 2019). The large number of Muslims who perform the special Hajj and Umrah has an impact on the increasing number of agents or organizers of Hajj and Umrah trips.

Being able to go to the Holy Land is the dream of every Muslim who wants to complete their worship. To do so, a considerable amount of effort is required, especially for those from the middle to lower classes, due to the high cost of Hajj or Umrah or both. Even 
without queuing for years and being offered a more affordable package, for most people the Umrah costs are still quite burdensome. In that complicated situation, it turns out that there is another path to the Holy Land that can reduce the cost of the trip, namely the Umrah backpacker.

Backpacker is a term used for travelers with a minimal budget whose participants can explore any place they want around the world, look for cheap things, and enjoy every detail of the trip. Although it can be adjusted to the budget, this method is not free from various risks. The nature of the backpacker is synonymous with traveling alone, but when doing Umrah, they can also invite a few friends, or join other Umrah backpacker communities, especially for the newbies. Besides minimizing the possibility of getting lost and other risks during Umrah, this method can also reduce costs, like transportation and lodging costs while in the Holy Land can be shared. Even so, this independent trip still gets a visa from an official Umrah travel agency. ${ }^{1}$

Umrah backpackers also reduce other costs such as eliminating for dispatching guides and travel agents from Indonesia, lowering lodging classes, marketing costs, souvenirs (suitcases, ihram clothes, or mukena/), and rituals. As for the cost of Umrah varies and depends on the package program. There are regular packages around IDR 26-27 million per person, while promotional ones are around IDR 16-17 million per person. However, there are other options for making Umrah trips at a lower cost. Elly Basrah Lubis, an umrah backpacker actor, said that Umrah can be run at a cost of IDR 8 million per person (Adityo Projo, 2017).

From some experiences have found, there are some people who want to go for Umrah with a minimal budget but they are not sufficiently informed about where to register themselves officially. There are several Umrah groups that are ready to leave but are still constrained by the number of participants. The minimum number of Umrah backpacker participants in order to depart is around 15-20 people. Other information regarding who wants to do an umrah backpacker and who is the guide is very difficult to find information about.

Along with the times, the Umrah backpacker, which was once done independently, becomes a special strategy widely used by Umrah travel agencies to include the umrah backpacker package as an option to attract the young. In several big cities, many have done the Umrah backpakcer, both those that have been managed by an Umrah travel agency or independently. The rise of the Umrah backpacker trend requires further research and analysis to determine the process of carrying out the Umrah backpacker trip, the obstacles in its implementation, the views of religious leaders, including government policies regarding this matter.

\section{Research Methods}

This study uses descriptive qualitative research, as stated by Bogdan and Taylor, which is a procedure that can be used to produce descriptive data in research in the form of written words. The use of the method is a practical way of describing and explaining the differences, implementation, impact, and motivation of the umrah backpacker pilgrims. Creswell (2003: 182) states that the more complete in presenting the narrative surrounding it, the better a qualitative study will be.

With this qualitative method, it is hoped that the study of the phenomenon of the implementation of the Umrah backpacker in Bekasi and Bogor City can be explored properly. The research sample used a purposive sample approach, in which the target informants had

1 Anonymous. https:/umrahnomad.com/biaya-umrah-backpacker/. Accessed on Desember 4, 2019. 
been predetermined. For this research, the selected informants included 5 infomants of umrah backpacker congregations, 3 informants of the Umrah Pilgrimage Tour Organizer (PPIU), 3 of informants of the Directorate of Umrah, and Special Hajj of the Ministry of Religious Affairs, 2 informants of religious figures.

\subsection{The Problem of the Multiple Interpretations of Umrah Backpacker}

The Umrah backpacker polemic, particularly regarding practice and regulations, cannot be detached from the definition of its term: "Umrah backpacker", which has not been agreed upon by the parties concerned. The definition of its term is very essential. Because, there is confusion in understanding the term of the Umrah backpacker.

The law of Fiqh states that Umrah means a trip to visit the Baitullah (Ka'bah) to take a series of worship (thawaf, sa'i and tahalul) with terms and conditions established by the Sharia (syari'at). The law of Umrah is Sunnah for every Muslim who is able to carry it out. Its implementation can be at any time, apart from the day of Arafah (9 Zulhijjah), and Tasyrik days $(11,12$, and 13 Zulhijjah).

Meanwhile, the term 'backpacker' is taken from English. According to the Cambridge Dictionary, a backpacker is a person who travels with a backpack, and in Indonesian, it is also interpreted with the same meaning. The term 'backpacker' then became a familiar wording in the ears of the moderns, especially the young people in Indonesia. Nowadays, when one hears the word 'backpacker', they will immediately go to a solo trip/vacation/picnic to a certain destination with a specific purpose, and with a backpack to store enough necessities during the trip. Commonly, the most important is they will prefer a low cost trip, or get prepared themselves for a minimalist/cheap budget (Anton Prasojo, 2018: 3).

Along with the blooming of this new market segment that has begun to be glimpsed by travel agency owners who already have an Umrah license number as the fundament for their selling value, there have been various offers of cheap Umrah packages that keep springing up, which are more commonly referred to as "Umrah backpacker." Typically, Umrah service bureaus have two mainstay packages, namely, the exclusive Umrah package and the regular one. Even though it is low-priced, the Umrah backpacker is still professionally organized. Because this type of Umrah is also under the supervision of official travel agencies, which, if it cannot be properly guarded, it will be sanctioned by a blacklist from the Kingdom of Saudi Arabia (Menur Kusumaningtyas, 2018: 230-231).

Departing from these multi-interpretive definitions, the term 'Umrah backpacker' then reap the pros and cons. Established on the field finding, it can be concluded that, in fact, even though all Umrah backpacker pilgrims have legally registered through an Umrah travel service provider, their Umrah trips are still considered illegal, as has been assumed so far.

Technically, the pilgrims of umrah backpacker still get visas from the PPIU, but there is flexibility for them to determine their companions, hotels, modes of transportation and the pilgrimage travel agenda in Mecca and Medina.

Thus, this study confirms that in substance, there is actually no such thing as Umrah backpacker, since all Umrah pilgrims who are assessed through the 'backpacker' route registered themselves through official travel services. It is called as Umrah backpacker because it has differences from the conventional types of Umrah, especially in terms of costs, companionship, accommodation, transportation, and so on.

Based on the finding, the definition of Umrah backpacker is not 'illegal Umrah,' but a category of Umrah that offers pilgrims the flexibility in matters as mentioned above. Hence, 
aside from visits to Saudi Arabia to perform rituals of worship, the term "Umrah backpacker" must be distinguished from the term "backpacker" which is frequently used by the public.

\subsection{The Regulations of Umrah Backpacker}

According to the Head of Sub-Directorate for Monitoring and Supervision of Umrah and Special Hajj of the Ministry of Religious of the Republic of Indonesia, Nur Aliya Fitra, all matters related to the organizing and implementation of Umrah must refer to Law No. 8 of 2018 and Regulation of the Minister of Religious Affairs (PMA) No. 8 of 2008. According to the law, Umrah must be carried out by PPIU (Umrah Trip Organizer) which has permission from the government through the Ministry.

Furthermore, the mentioned regulations also specify the Minimum Service Standards (SPM), one of which is the obligation to arrange companions when carrying out Umrah. Meanwhile, the Umrah visa is issued by the visa provider, which is usually PPIU.

The Directorate of Hajj and Umrah of the Ministry of Religious Affairs had discussed the issue of Umrah backpacker, although there have never been complaints from the public who feel aggrieved by the implementation of this type of Umrah. After all, the Ministry of Religious Affairs does not have the authority to handle complaints of the matter. It is the Ministry of Foreign Affairs that handles every Indonesian citizen who deals with the immigration authorities and the Saudi Arabian police.

As remarked in the methodology chapter, the sample of this research was conducted in two cities: Bekasi and Bogor.

\section{The finding in Bogor}

Deden Mahmuddin, the staff of Integrated Hajj Computerized System (Siskohat) of the Ministry of Religious Affairs, explained that in Bogor, West Java, there was no PPIU providing the Umrah backpacker. The regional Ministry of Religious Affairs in Bogor regularly conducts monitoring and intensive communication with 16 PPIU managers in the city.

Matters of permits, departure, problems and constraints faced, were some of the things that were always discussed during monitoring and communication. The information of the Umrah pilgrims have been input into the Siskopatuh system. Siskopatuh is the Computerized Integrated Management System for Umrah and Special Hajj created by the Ministry of Religious Affairs itself.

In addition to monitoring and communication, there was also socialization to PPIU managers regarding the Memorandum of Understanding (MoU) of the regional Ministry of Religious of West Java with the local Police. The MoU contains the supervision and law enforcement of the implementation of the special Hajj and Umrah.

\section{The Finding in Bekasi}

As for the research finding in Bekasi, Sri Siagawati, Head of the Hajj and Umrah Organizing Section of the regional Ministry of Religion in the City of Bekasi, stated that there have been several cases regarding Umrah organizing, such as the case of Bengkel Rohani, whose status is neither PPIU nor consortium (travel tours in collaboration with PPIU), but offers Umrah packages. 
Then, there was the Alghoni Assalam case, whose status is not included in the PPIU, but a consortium in collaboration with Umi Travel. There was also the case of Permata Travel related to 42 Umrah pilgrims who had been abandoned in Medina. From this series of cases, none of them are related at all to the matters of Umrah backpacker. In Bekasi itself, there are no flyers, posters, or banners containing information on the Umrah backpacker issued by certain travel agencies or PPIU.

In the aspect of cross-sectoral supervision, both in Bogor and Bekasi, there was socialization to PPIU managers regarding the MoU of the regional Ministry of Religious Affairs and local Police of West Java, which contained supervision and law enforcement of the implementation of special Hajj and Umrah pilgrimages. In fact, the Hajj and Umrah Affairs Section of Bekasi also communicates regularly with PPIU managers through the Whatsapp group.

As in the applicable provisions for issuing Umrah passports at the Immigration office, they must first obtain a recommendation from the regional and district Ministry of Religious Affairs. In this regard, this year as many as 47 PPIUs in Bekasi have gained permission to hold Umrah services. Meanwhile, the data of the Umrah pilgrims has been input into the Siskopatuh.

\subsection{The Views of Religious Leaders on Umrah Backpacker}

In addition to regulatory aspects related to administrative legality, Islamic views are also important because they link up to the legality of the Umrah according to Islamic law. The following are the thoughts of several religious leaders regarding the legal status of the umrah backpacker.

KH. Mir'an Syafii, the Chairman of the Indonesian Ulema Council (MUI) of Bekasi City, conveyed that the implementation of Umrah with the backpacker scheme does not meet the pillars and procedures of Umrah that are in accordance with Sharia if not accompanied by muthawif who understands the position of Sharia in the implementation of Umrah. With this scheme, there is also an apprehension that there will be no schedule for pilgrimage trips to the graves that are usually held by regular Umrah. If this occurs, the perfection of Umrah also needs to be a concern.

It is very important to get guidances on carrying out Umrah, so the rituals does not get out of the way of the pillars and procedures of Umrah. There was once a case in 2008 , when an Umrah pilgrim thought that he could perform Umrah on his own without muthawif guidance while in Saudi Arabia. When he performed Tawaf, he was accused of pickpocketing and had to deal with the Saudi Arabian police. Because he did not have mastery of Arabic and English, as a result, he could not explain the real events well, and ended up in prison, even though, at that time he only took the wallet that had fallen. Thr case shows us how important guidance amd security are in performing Umrah and Hajj. Such problem can be handled properly if it was under PPIU's surveillance.

Therefore, it is extremely necessary for the authorities to provide understanding to the Muslim public in Indonesia regarding the pillars, procedures, and all matters related to the implementation of Umrah and Hajj before leaving for Saudi Arabia. In Shari'a, Islam clearly regulates the command to obey Allah, the prophets and the leaders.

Meanwhile, H. Hasbullah, the caretaker of Pesantren Darul Ulum Bantar Kemang, Bogor, said that the implementation of Umrah is the right of every Muslim citizen because it is prescribed in Islam, even though the law is Sunnah. Nevrtheless, it is still necessary to pay 
attention to the legislation that have been regulated, including the need for assistance during Umrah, especially concerning the pillars and procedures of Umrah.

Taking into account the regulations and considerations above, the prospective Umrah backpackers need to do several things. Firstly, they must propose the name of their companion during Umrah. Secondly, they have to inform their travel plans, as well as details on the readiness of accommodation and supplies for performing Umrah. Those information are necessarily important, considering that Umrah is a physical form of worship that requires anyone to be physically and mentally prepared.

On the other hand, the government must also innovate in providing services to the Muslim community concerning the need to carry out Umrah. It will be related to people with minimal budgets, but with high enthusiasm to performing Umrah. That way, they can choose the Umrah backpacker scheme which is relatively cheaper.

Apart from referring to government regulations and Islamic law, it is important to comprehend the ins and outs of the Umrah backpacker from the point of view of a travel manager or an Umrah travel service provider. Although not many provide backpacker umrah packages, their assessment as a service agency should be counted.

The Division of Regulation and Development of the Association of Muslim Hajj and Umrah Organizers of the Republic of Indonesia (AMPHURI) Ali Basuki explained some considerations related to Umrah regulations. Currently, AMPHURI supports 445 PPIUs out of 1014 PPIUs throughout Indonesia. It always provides socialization, strengthening and dissemination of all information regarding the regulations and administration of Hajj and Umrah. Moreover, it is also a place to communicate and stay in touch, including discussing the matters of Hajj and Umrah.

Ali Basuki stated that the emergence of the Umrah backpacker phenomenon indirectly deconstructed the PPIU by giving the impression that registering for Umrah through this institution was quite expensive. However, this phenomenon also indicates an increase in the religiosity of the Muslim community in Indonesia.

According to him, the Umrah backpacker is not illegal. What is actually illegal is the Umrah Arisan System, which is also an illegal investment. Hence, the Umrah backpacker service needs a clearer law enforcement in order to comply with the principles and regulations regarding the implementation of Hajj and Umrah.

Generally, the Umrah backpacker is organized by a community, although it is impossible for them to depart without obtaining a visa that can only be released by an official visa provider. If the PPIU officially provides the Umrah backpacker package, it is actually an innovation of PPIU itself, as long as all the stipulated provisions are implemented and the rights of the pilgrims to receive security and tranquility are still well cared for and guarded.

Furthermore, it should also be noted that the visa issued by the Saudi Arabian Embassy is definitely an Umrah visa not a tourist one. Hence, anyone who is going to perform Umrah, including those who take the Umrah backpacker scheme, still has to report it to PPIU or an official visa provider. PPIU is concurrently an official visa provider because it has been registered with the government of Saudi Arabia as the party entitled to issue visas. Thus, the naming of the term Umrah backpacker is actually not quite right because in practice, it is handled by the PPIU, particularly regarding visas. (The discussion of the definition of the term 'Umrah backpacker' was explained above in point 1).

In some application of the rules, AMPHURI did not accord with the minimum service standard regarding the hotel category that must be 4-star, and the return flight must be with the same airline as the departure. It is better if the rule is reviewed and the use of airlines 
may be different so that travel expenses are not too high. Hence, AMPHURI recommends the government to provide flexibility in the Minimum Service System for Umrah pilgrims.

On different occasions, Umar Toha as Director of the Umrah Travel Branch of PT. Madinah Iman Wisata Kota Bogor, emphasized that he had never organized an Umrah backpacker package. Reflecting on his experience in organizing the best regular Umrah in all aspects, it turns out that there are still complaints, such as about food quality, five-star hotel room facilities, etc. Therefore, he cannot imagine preparing for Umrah backpacker services which are all minimal. However, complaints arise because of the inconvenience, which holds the potential to disturb the solemnity in performing Umrah.

And there was once a prospective congregation who signed up for Toha's travel service and told his experience of joining the Umrah backpacker. He said that he had to wait a very long time for his next flight during the transit. Here, we can see that the Umrah backpacker facilities are definitely far from regular Umrah services.

Toha continued that if there are travel agencies that wanted to organize the Umrah backpacker, they have to be open and honest with potential consumers of their services. Don't let the public be interested just because of the low cost. In terms of market share, the package is indeed suitable for young people, so there needs to be a particular age category because backpacker-style travel definitely requires stronger physical and mental strength.

Moreover, the Umrah supervisor must also master all aspects of the pillars and procedures of Umrah. It is recommended that the Umrah pilgrims choose a certified supervisor. And as the leading sector, should the Ministry of Religious Affairs monitor and ensure that the implementation of the Umrah backpacker can run in accordance with state regulations and Sharia.

In another view, Adha, the Umrah Operations Division of PT Khadim Permata Tour, Kota Bogor (PPIU), explained that his party had never held an Umrah backpacker. This type of Umrah is starting to become a trend because there may be information that people can apply for individual visa, and of course, there is the lure of cheap tickets.

So far, the data of the Umrah pilgrims must be entered in the Siskopatuh System for monitoring, which is also carried out at the Umrah counters at the airport. The officer will make unannounced checks and inspections via a barcode held by the congregation. Yet, the checking is usually done randomly and sometimes only to one person. The barcode will show the complete data of the pilgrim, including their visa provider. The visa provider status must be a member of the IATA association which is authorized by the Saudi Arabian embassy.

The Umrah backpacker is a possible alternative about cost. Nevertheless, each congregation must have a Siskopatuh ID Card so they can go to perform Umrah. Thusly, it is impossible to perform umrah independently, and without going through the PPIU. In this case, Adha suggested the government to keep on implementing the steps that have been regulated in the PMA and there must be an inspection at the airport.

In contrast to previous views, Faisal from PT Khafilah Akbar, Jatibening, Bekasi, admitted that his travel agency provides Umrah backpacker services. This stems from the mandate of his father who died in 2005, to continue organizing Hajj and Umrah. Her sister, Elly Zarni Lubis, in 2015 attended an Umrah backpacker training held by someone who had developed this type of umrah Earlier. Yet, he did not have congregations, and Elly asked his permission to organize the umrah backpacker.

Elly then formed a tour leader team who would bring and form a group of 10-40 congregations. They booked the tickets themselves, but the LA (Land Arrangements) and the visa are taken care of by PT Khafilah Akbar. The budget is adjusted to the ability of each group. 
The Umrah backpacker is actually the result of trimming unnecessary expenses of regular ones. For instance, they were looking for cheaper suitcases, and the muthawif chosen to accompany the pilgrims were Indonesian students in Medina. The tour leader's duty is to guard the congregations in administrative matters, while the muthawif assists the affairs of worship.

According to Faisal, the simple definition of the Umrah backpacker is Umrah with a lower cost than the regular one, the muthawif are not brought from Indonesia, and there is no uniform for the congregations, except for women wearing the same headscarf and slyer. Thence, the Umrah backpacker can be said to be the same as the regular packages. The accommodation is also adjusted to the range of three and four-star hotels, and some even choose five-star's.

So, the Umrah backpacker is more about independence. What distinguishes it from regular ones is the technical service that sticks to the low cost principle. Matters related to administration remain legal. The status of PT Khafilah Akbar itself is a consortium, but has not become a PPIU. Even so, not all Umrah organizers provide the Umrah backpacker services. Because, they have different views about the advantages, disadvantages, and obstacles of this kind of Umrah.

\section{The Experiences of the Umrah Backpacker}

Soekardijanto Edy from Cikarang, Bekasi, had once experienced the Umrah backpacker program. He gained information about the program from the pesantren where he teaches. At that time, there was a donor who wanted to send the pesantren teacher off for Umrah, and in 2016, he happened to be the chosen one to go for 11 days under the Khafilah Akbar travel service. It was his first time to perform Umrah.

Interestingly, at that time, there were none came from the same city as Edy. The people in his group came from various cities, like Palembang, Semarang, Malang, and other cities. Unfortunately, Edy did not know for sure the exact amount of the Umrah backpacker fee, because it was borne by the foundation where he taught. His visa was also immediately taken care of by the travel agency, while he only took care of his passport.

Edy revealed that during the trip, he did not experience any significant problems. His entourage departed using Air Asia and returned with the Etihad airline. Arriving at the Holy Land, transportation and hotels had been taken care of by the travel agency. In terms of service, he felt comfortable joining the Umrah backpacker program. In fact, if there is another chance, he is willing to go for it through the same scheme.

Besides Edy, there is also an experience of someone who does not want to be named. Let's call him Informant II. He got information about the Umrah backpacker program from a friend. Although he is not an active member of the Umrah backpacker community, he has undertaken this Umrah route twice in 2017 and 2019 through Nursa travel agency. In his group, there were also those from the same city as him.

His motivation for joining the program was because he wanted to face God directly in His House (Ka'bah), then made a pilgrimage to the Prophet's grave, as well as in order to gather with alumni of the same class at the pesantren. Regarding the cost, he spent 16 million on his first Umrah, then 18-19 million for the second one.

He admitted that he did not experience problems during the registration and visa application process. Likewise, he felt fine and there were no significant obstacles during the 
trip. He actually felt comfortable with the accommodation and transportation services, which at that time were taken care of by his friend's travel agency.

In fact, according to him, the services provided exceeded his expectation. Except for his muthawif, he joined the regular Umrah group. Recalling his two experiences of doing the Umrah backpacker, he wants to do another Umrah backpacker if there is another chance.

Next, there is the experience of Informant III. Just like Informant II, he also received information on the Umrah backpacker program from a friend and used the same travel agency, Nursa Travel. Until now, he is an active member of the Umrah backpacker community in the city where he lives. Even so, he only joined the travel program once in 2017. He is motivated by the program because of the low cost and can go together with his friends. The cost he spent in 2017 was 16 million rupiah. He also felt that at that time there were no significant matters during the trip, both in Indonesia and in Saudi Arabia.

Regarding tranquility during the Umrah trip, informant III felt comfortable and considered it good, especially the accommodation provided was a 3-star hotel. From that pleasant experience, he wants to return to carrying out the Umrah backpacker through the same travel. Still, he hopes that the travel organizer should add more travel routes other than Makkah and Madinah.

\section{Opportunities and Challenges of the Umrah Backpacker}

Organizing the Umrah backpacker service does not mean providing modest services to consumers. According to Elya Surie, one of the organizers of the Umrah backpacker, this kind of umrah trip actually has a number of advantages over the regular ones. Besides being definitely cheaper, the services can also be adapted to the needs of group members of the congregation.

For example, when accompanying last year's Umrah, Elya had received a request to arrange a schedule to visit a date palm garden in Medina. At that time, some members were interested in experiencing the dinner package in the middle of a date plantation.

Other than that, according to Elsa Hasnani, founder of Fandiego Travel in Cikeas, Bogor, West Java, said that behind several advantages, the Umrah backpacker still has weaknesses compared to regular packages. One of them is about the cost of airplane tickets. This component significantly affects the cost of the independent Umrah packages offered. The travel is very dependent on promotional tickets. Without them, the price of the Umrah backpacker can be as expensive as the regular ones. As a consequence of discounted tickets, consumers cannot freely determine their departure and return schedules. Not only that, the airlines also usually apply a quota system for cheap ticket prices.

Thus, it is not impossible for one to pay a higher ticket price than others. This is different from the regular packages that are commonly offered by Umrah travel agencies. For the regular ones, they usually have fixed departure schedules, like three or four times a year. The price offered is fixed and not much affected by the price of airplane tickets. Learning from the experiences of Elya and Elsa, the departure schedule for the Umrah backpacker also depends heavily on the time availability of the group leader (Tempo, 2019: 102-108).

The challenges faced in organizing the Umrah backpacker can at least be represented into three points, namely segmentation, targeting, and positioning (Apriliana \& Melinda, 2018: 22):

1. Market segmentation carried out by Umrah backpacker service providers is among the middle class. This middle segmentation was chosen because this group has many young 
people who desire to perform Umrah because following trends and enjoy the type of trip with a minimal budget.

2. The targets of the Umrah backpacker are the Muslim students' communities at a university, the youth community of Qur'an, and female's or women's communities.

3. The Umrah backpacker service providers are positioning themselves to focus on the services offered. For example, they offer Umrah backpacker with several package options where consumers can choose or determine destinations after the mandatory Umrah activities, so that they are not only doing Umrah, but also traveling to other places.

\section{Conclusion}

Based on the questions on the problem identification which aligns with the findings in the field, there are several conclusions as follows:

1. Pros and cons of the Umrah backpacker due to multiple interpretations of its definition. One of them is juxtaposing the word backpacker after the word Umrah. Relied on the facts in the field, the Umrah backpacker actually does not exist, because the practice is not much different from regular ones. If it is necessary to define it, the Umrah backpacker is defined as an Umrah trip that is different from conventional ones, especially in terms of costs, companionship, accommodation, transportation, and so on. On this basis, the Umrah backpacker is not illegal, because it is registered officially through the PPIU.

2. Should all matters related to the organizing and implementation of the Umrah pilgrimage refer to the Law No. 8 of 2018 and Regulation of the Minister of Religious Affairs (PMA) of the Republic of Indonesia No. 8 of 2008. These lawa state that Umrah registration services must be carried out by PPIU (Umrah Service Organizer) which has received permission from the government through the Ministry concerned.

3. The Umrah backpacker does not fulfill the pillars and procedures of Umrah which is in accordance with the Shari'a if it is not assisted by muthawif who understands the position of sharia in the implementation of Umrah. The Government also has to be innovative in addressing the enthusiasm of the Muslim community for the needs of Umrah.

4. Based on the experiences of several informants who have taken the Umrah backpacker route, it was found that there are not many travel agencies provide the Umrah backpacker services. They do not experience problems in managing the visa, because they are taken care of by authorized travel agencies who have obtained permission.

Regarding the service and provision of facilities, although it is not the same as regular ones, the informants confirmed that they felt comfortable because transportation, accommodation and consumption are quite well arranged by the travel agency. If given another opportunity, they expressed a desire to re-perform Umrah with the same scheme.

\section{Recommendations}

1. It is better if the Government and Umrah service providers sit together to discuss the definition of the term "Umrah backpacker." Hopefully, there is no Umrah that has been officially registered, but considered illegal just because its term has multiple interpretations. 2. Considering the people's enthusiasm for carrying out Umrah, even through the Umrah backpacker, should the government simplify regulations related to the issue, the Law no. 8 of 2018 and PMA no. 8 of 2018, so that it does not make it difficult for people who do not have a maximum budget for performing umrah. 


\section{References}

[1] Afidah, Vivi Nurul \& Syahril Romli. 2019. Strategi Pemasaran Paket Ibadah Haji Dan Umrah Dalam Merekrut Jamaah Di PT. Sela Expres Tour Kota Pekanbaru. Jurnal Riset Mahasiswa Dakwah Dan Komunikasi, vol. 1, no. 3, Juli 2019.

[2] Alim, Syaiful. 2011. Menyingkap Rahasia Umrah dan Haji Mabrur. Yogyakarta: Safirah. Anonymous. $\quad$ http://www.kemenag.go.id/index.php? $\mathrm{a}=$ artikel\&id=21561 Anonymous. https://umrahnomad.com/biaya-umrah-backpacker/. (Desember 4, 2019)

[3] al-Bukhari, Muhammad Ibn Isma'il Abu Abdullah. (n.d). al-Jami' al-Shahih, vol. VII. Beirut: Maktabah Tuq al-Najat.

[4] Dewi, Subkhani Kusuma. 2017. Trend Wisata Umrah: Antara Meneladani Sunnah dan Turisme Spiritual. Jurnal Empirisma, vol. 26, no. 2, July 2017.

[5] Departemen Pendidikan dan Kebudayaan. 1990. Kamus Bahasa Indonesia. Jakarta: Balai Pustaka.

[6] Gautama, Aria. 2011. Fenomena Pekerja Anak Yang Bekerja di Perkebunan Sawit. Undergraduate thesis of Sociology student at Faculty of Social and Political Sciences. Lampung: University of Lampung.

[7] Hindle, Natalie, and Andrew Martin, Robert Nash. 2015. Tourism development and the backpacker market in Highland Scotland. Journal of Tourism and Hospitality Research vol. 15(3) 178-192.

[8] Kaelan. 2005. Metode Penelitian Kualitatif Bidang Filsafat. Yogyakarta: Pradigma.

Kusumaningtyas, Menur. 2018. Umroh Backpacker: Prospek, Kendala dan Strategi Pengembangannya. Media Mahardhika vol. 16 No. 2 Januari (2018).

[9] Mahjuddin. (n.d). Tafsir Tarbwai: Kajian Ayat-Ayat Al-Quran dengan Tafsir Pendidikan, 2nd ed.

Moleong, Lexy J. 2012. Metode penelitian Kualitatif. Bandung: Remaja Rosda Karya.

[10] Nazir, Moh. 2009. Metode Penelitian. Bogor: Ghalia Indonesia.

Oktaviani,Zahrotul\&Ani Nursalikah. (n.d.).MenagLobiKuotaDasarJamaahHaji Naik Jadi 231 Ribu. https://republika.co.id/berita/q1xf3b366/kuota-dasar-jamaah-haji- indonesia-naikjadi-231-ribu (18 March 2020).

[11] Poushter, Jacob \& Janell Fetterolf. (n.d). How people around the world view religion's role in their countries. https://www.pewresearch.org/global/2019/04/22/how-people-around-the-world-viewreligions-role-in-their-countries/. (18 March 2020).

[12] Prasojo, Anton. 2018. Berangkat Umrah Ala Backpacker: Berbagi Pengalaman Detail Teknis Pelaksanaan. Sleman: Deepublish.

[13] Sahita, Apriliana Lailatul Nur \& Tina Melinda. 2018. Feasibility Study of Religion Tourism Business for The Young People. Trikonomika, vol 17, no. 1, June 2018.

[14] ash-Shiddieqy, Teungku Muhammad Hasbi. 1998. Pedoman Haji. Semarang: PT. Pustaka Rizki Putra.

[15] Sudjijono, Anas. 2006. Pengantar Statistic Pendidikan. Jakarta: Raja Grafindo.

[16] Tidjani, Shofia \& Patmi Pawianti. 2015. Analisis Persepsi Jamaah Umrah Dalam Penerapan Prinsip Syariat Islam Pada Pelayanan Di PT. Cahaya Azami Wisata Jakarta. Jurnal islaminomic, vol. 6, no. 2, (August2015).

[17] Sucipto. 2013. Umrah sebagai gaya hidup, eksistensi diri dan komoditas industri: menyaksikan perubahan keagamaan warga kota. Jurnal Kontestualita, vol. 28, no. 1.

[18] Sugiyono. 2012. Metode Penelitian Kuantitatif, Kualitatif dan R\&D. Bandung: Alfabeta.

[19] Supardi. 2005. Metodologi Penelitian Ekonomi dan Bisnis. Jakarta: UUI Press.

[20] Supriyadi. 2017. Panduan Melaksanakan Ibadah Umrah Berbasis Android. Prossiding Lembaga Penelitian Pengembangan Pembelajaran dan Pengabdian Kepada Masyarakat. Semnas IIB Darmajaya. [21] _. 2019. Anak Milenial dan Hobi Berlibur Yang Menumbuhkan Dunia Pariwisata. Jakarta: Tempo Publishing. 